\title{
AZ ELÉRHETŐSÉG ÉS AZ IDEGENFORGALOM KAPCSOLATA
}

\author{
(The Connection between Accessibility and Tourism)
}

\section{TÓTH GÉZA - DÁVID LÓRÁNT}

Kulcsszavak:

elérhetóség turizmus loglineáris modell gravitációs modell

Az idegenforgalom és a közúti elérhetöség közötti kapcsolat vizsgálata meglehetősen sok módszertani problémát vet fel. Bár a kapcsolat látszólag evidensnek tünhet, mégis a statisztikai mérés meglehetösen nehéz. Így mi nem is a kapcsolat szorosságát igyekeztük vizsgálni, inkább sajátosságait, illetve összetevöit a magyarországi idegenforgalmi régiỏkban loglineáris modell segitségével. Elemzésünk második részében gravitációs modell segitségével próbáltuk megbecsülni a belföldi többnapos utak nagyságát, s hasonlitottuk össze a becsült és a valós értékeket. Ezzel igyekeztük feltárni a magyarországi belfóldi turisztikai áramlatok sajátosságait.

\section{Bevezetö}

A közlekedés a turizmus létezésének egyik alapfeltétele. Egy olyan kulcselemről van szó, mely a turistákat összekapcsolja az általuk elérni kívánt célterületekkel. A turizmus és a közlekedés közötti kapcsolatot bár korábban meglehetösen széles körủen megvizsgálták, mégis jelentős kutatási hiányosságok maradtak a kérdésben. Mint Knowles (1993) rámutat, a kutatók a közlekedést sok esetben, a turizmus kapcsán csak passziv elemként vették figyelembe, s nem a turisztikai tevékenység integráns részeként.

Hale és Page (1999) négy vizsgálandó területet jelöl ki a közlekedés és a turizmus határterületén: a forrás és a célterület összekapcsolása, mobilitás és hozzáférés biztosítása a célterületen belül, mobilitás és hozzáférés biztosítása egy aktuális turisztikai vonzerővel rendelkező területen belül és egy rekreációs útvonalon való utazás elősegítése, mely önmagában is turisztikai élményt jelent.

A közlekedés és a turizmus közötti kapcsolat vizsgálatának egyik módszertanilag legösszetettebb problémakörét az jelenti, hogy a közlekedési teljesítményekbỏl hogyan lehet leválasztani a turisztikai célú mozgásokat. Több olyan közlekedési ág van ugyanis, melyet mind a rezidens állampolgárok, mind pedig a turisták előszeretettel használnak, így a szerepek szétválasztása némi problémába ütközik.

Hallsall (1982) határozta meg az alapvető kapcsolatot a szabadidő és a közlekedés között. E szerint: a közlekedés egy igen lényeges része a turisztikai (rekreációs) viselkedésnek, emellett segíti a rekreációs célok elérését, illetve maga is rekreációs tevékenységet jelent. A relatív utazási költségek folyamatos csökkenése és a távolságok lerövidülése drámaian megnövelték a rekreációs célú utazások iránti igényt. 
Tóth Géza - Dávid Lóránt : Az elérhetőség és az idegenforgalom kapcsolata.

Tér és Társadalom 23. évf. 2009/3. 45-62. p.

Különösen a gépkocsi használat fejlődése növelte meg az utak távolságát és a turisztikai jellegủ utazásokon belüli arányát.

A közlekedés területi hatásainak, $\mathrm{s}$ ezen belül a turizmusra gyakorolt hatásainak vizsgálatakor egyre inkább elterjed az a nézet, ahol kővetkezetesen területfelhasználási problémakörről és rendszerről beszélnek, ezzel is világossá téve, értékelhetö, szoros és kölcsönös összefüggésrendszerről van szó. Ebben az összefüggésben: „Az elérhetöség azt adja meg, hogy a területfelhasználási-közlekedési rendszer milyen mértékben képes lehetỏvé tenni egyének (csoportjaik) és áruk számára, hogy elérjék a különböző tevékenységeket, illetve célpontjaikat a közlekedés segítségével." (Geurs-Ritsema 2001,36)

Az elméleti modell (1. ábra) központi részét a területhasználati-közlekedési rendszer jelenti, mely a területhasználat és a közlekedés kölcsönösen egymástól függö rendszere. (A modellt most elsősorban a turizmus szempontjából kívánjuk ismertetni.)

A területhasználati alrendszer tartalmazza a területhasználati típusok térbeli eloszlását (pl. a területhasználat jellege, a beépités sürủsége, térbeli különbözösége, illetve a turisztikai desztinációk térbeli elhelyezkedése, illetve jellege).

Ennek az alrendszernek a másik összetevője az emberi tevékenységek helyszínei (pl. ilyen a rekreációs tevékenység valamennyi összetevőjének térbeli elhelyezkedése).

A területhasználatot és a jelzett tevékenységeket kétirányú alrendszer kapcsolja össze: a tevékenységek térbeli megoszlása meghatározza a területhasználatot, mely szintén visszahat a tevékenységekre, illetve azok térbeli megoszlására. Vagyis a turisztikai desztinációk területhasználatát mind annak jellege, beépítése, mind pedig a rekreációs tevékenység konkrét helyszínei egyaránt kölcsönösen meghatározzák.

A közlekedési alrendszer a közlekedés iránti igényt (a turisztikai célú áramlások), illetve az infrastruktúra által biztosított szolgáltatásokat tartalmazza (az infrastruktúra fizikai jellemzöi, pl. kapacitás, sebességhatárok; az infrastruktúra használatának jellemzői, pl. az útszakasz forgalmi viszonyainak időbeli alakulása, a tömegközlekedés menetrendje stb.).

A közlekedés iránti igény és az infrastruktúra által biztosított szolgáltatások között is kétirányú kapcsolatrendszer figyelhető meg. Az infrastruktúra által biztosított szolgáltatások meghatározzák a közlekedés iránti kereslet jellegét és nagyságát (az idő, a költség és más összetevőkön keresztül). A közlekedés iránti igény továbbá hatással van az infrastruktúra által biztosított szolgáltatás minőségére, a szolgáltatási szintre.

A területhasználati és a közlekedési alrendszert kétirányú kapcsolatrendszer köti össze: a turisztikai desztinációk térbeli eloszlása váltja ki az igényt, mely arra irányul, hogy a közlekedési rendszer győzze le az otthon és az elérni kívánt desztináció térbeli elhelyezkedése közötti távolságot. Ezzel szemben viszont az egyes helyszínek elérhetősége meghatározza az egyének és háztartások utazási döntéseit, mely változásokat eredményez a területhasználati alrendszerben.

A kontextuális faktorok alapvetỏen meghatározzák a területhasználati-közlekedési rendszer müködését és hatásait, az idegenforgalom vonatkozásában is. Ide sorolhatók a gazdaság jellemzői (a gazdasági növekedés szintje elsősorban a kibocsátó területek vonatkozásában); a népesség demográfiai, szociológiai, illetve kulturális 
Tóth Géza - Dávid Lóránt : Az elérhetőség és az idegenforgalom kapcsolata.

Tér és Társadalom 23. évf. 2009/3. 45-62. p.

jellemzői (pl. a népesség kor és jövedelem szerinti megoszlása, a népesség [közlekedési] szükségletei, preferenciái); a környezeti állapot (a természetes eröforrások, mint például a fosszilis üzemanyagok mennyisége, a terület környezeti minősége); a technológiai fejlettség (információs és kommunikációs technológiák, jármú technológia). Végül, de nem utolsósorban a politikai döntések mind közvetlenül (közlekedési infrastruktúra-fejlesztések, üzemanyagokat terhelö adók, helyi döntések), mind pedig a kontextuális tényezökön keresztül indirekt módon kihatnak a területhasználatiközlekedési rendszerre.

\section{1. ÁBRA}

A területhasználati-közlekedési rendszer elméleti modellje

(A Contextual Model of the Land-use Transport System)

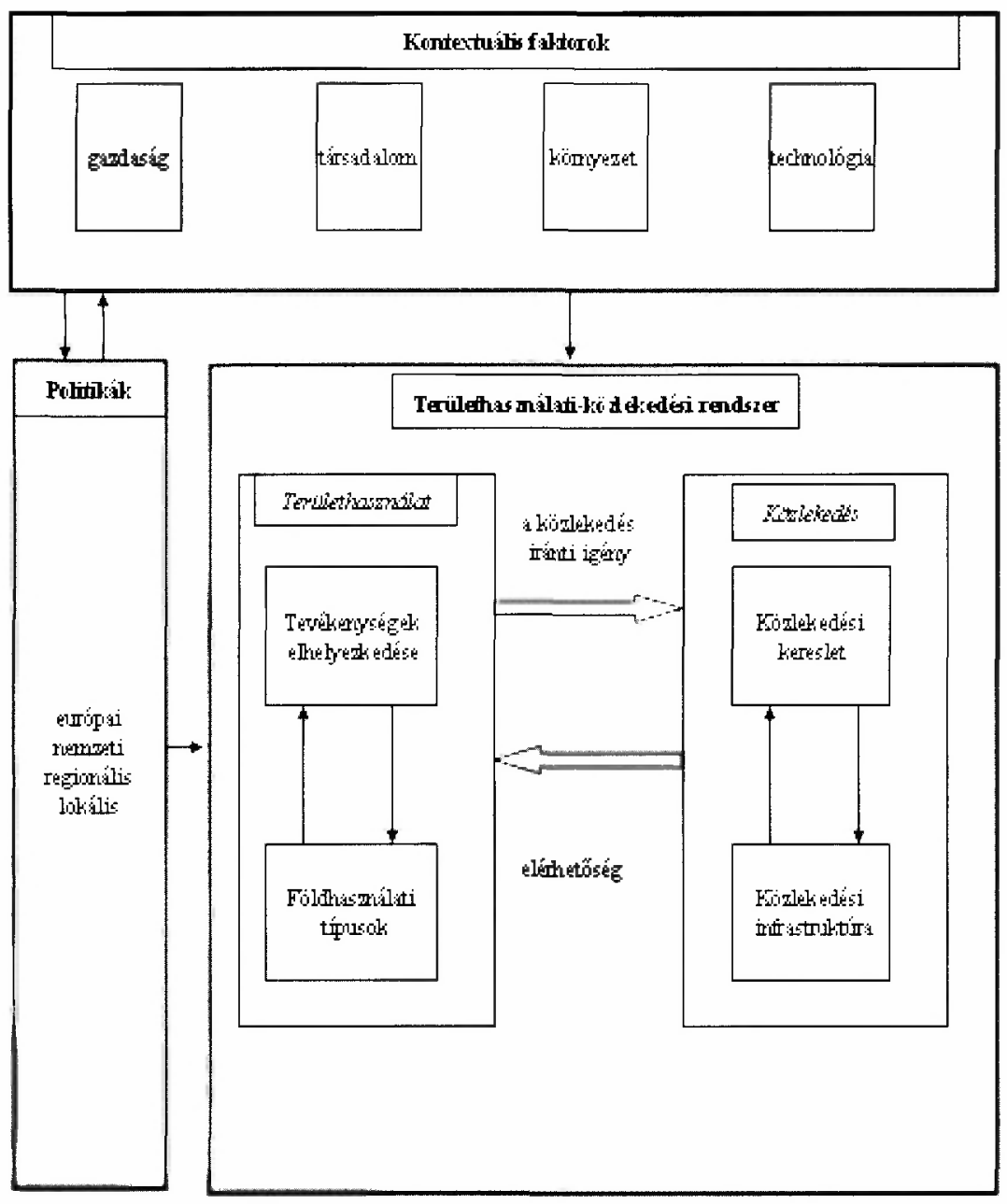

Forrás: Geurs-Ritsema (2001). 
Tóth Géza - Dávid Lóránt : Az elérhetőség és az idegenforgalom kapcsolata.

Tér és Társadalom 23. évf. 2009/3. 45-62. p.

A területhasználati-közlekedési rendszer, a kontextuális faktorok és a politikai döntések eredményeként alakulnak ki a területi folyamatok. A földrajz, illetve a regionális tudomány feladata, hogy e folyamatok hatásait mutassa ki, $\mathrm{s}$ lehetőleg próbálja meg bizonyos eszközökkel mérni. A mérés indikátorait két csoportba lehet sorolni. Az első csoportba azok a mutatók tartoznak, amelyek a területhasználati-közlekedési rendszeren belüli összefüggéseket írják le, ezeket közbenső indikátoroknak is nevezhetjük (ebbe a csoportba soroljuk a szorosan vett elérhetöségi indikátorokat). A második csoportba azok a mutatók sorolhatók, amelyek a jelzett rendszeren kívülröl származnak, vagyis a hatásokat szélesebb összefüggésben kívánják bemutatni (ide olyan társadalmi-gazdasági-környezeti indikátorokat sorolunk, amelyek a teljes területhasználati-környezeti rendszer helyzetét és folyamatait próbálják illusztrálni).

Az utazás költsége a turisztikai kiadások egyik fontos összetevője, de a távolság csupán egy a céldesztináció kiválasztási szempontjai közül. Több olyan turisztikai desztináció ismert, amely a versenytársaitól való viszonylagos távoli elhelyezkedése ellenére igen erős fejlődést mutatott. Sok esetben a nehéz elérhetőséget más vonzótényezők lényegében kiegyenlíthetnek, illetve olyan desztináció is elképzelhetö, ahol éppen a kedvezötlen elérhetőség jelenti a vonzeröt.

Egy hipotézis szerint a turisták az elérni kívánt desztinációkat először a helyi lehetöségek és vonzerők alapján választják ki. A döntési folyamatban a hasonló jellegủ adottságokkal rendelkező desztinációkat veszik figyelembe. Csak miután ez az elsődleges választás megtörtént, hasonlítják össze a desztinációkat elérhetöségük alapján. Így az elérhetőségnek elsősorban a potenciálisan felkereshető desztinációk egymással való helyettesítésében van szerepe. Azok a desztinációk viszont, amelyek versenyképes elönyöket képesek biztosítani a turisták számára, még akkor is jelentős számú turistát képesek vonzani, ha viszonylagosan rossz elérhetőséggel rendelkeznek. Az elérhetőség problémája így elsősorban azon desztinációk számára fontos, amelyek hasonló jellemzőkkel rendelkeznek (tengerpartok), míg az egyedi vonzerővel rendelkezők számára már kevésbé kiemelkedő (történelmi városok, fürdőhelyek). A jó elérhetőség önmagában nem jelenti a versenyképesség forrását.

\section{Az elérhetőség szerepe az idegenforgalmi bevételek alakulásában}

Vizsgálatunkban arra a kérdésre igyekeztünk választ keresni, hogy az idegenforgalmi szállásdíj-bevételek nagysága mennyiben kötődik a közúti elérhetőségi viszonyokhoz, vagy elsősorban az egyes régiók helyi sajátosságaitól függ-e.

Magyarországon 1998-ban alakították ki az idegenforgalmi régiók rendszerét. A régióbeosztásnál figyelembe vették az európai statisztikai rendszernek megfelelő NUTS 2 szintủ régiókat, melyeket a magyarországi szakirodalom tervezési-statisztikai régióknak nevez. E régiók határait módosították az idegenforgalmi régiók kialakításánál a kiemelt üdülőkörzetek határait figyelembe véve. Így a 7 tervezési-statisztikai régió módosításával jött létre a 9 idegenforgalmi régió. A két lehatárolás közötti különbséget mutatja a 2. ábra. Munkánk során elsősorban ezt a beosztást használjuk. 
Tóth Géza - Dávid Lóránt : Az elérhetőség és az idegenforgalom kapcsolata.

Tér és Társadalom 23. évf. 2009/3. 45-62. p.

TÉT XXIII. évf. 2009 a 3

Az elérhetöség és az idegenforgalom...

49

\section{2. ÁBRA}

A tervezési-statisztikai és az idegenforgalmi régiók közötti különbség Magyarországon

(Differences between the Planning-statistical and Tourism Regions in Hungary)

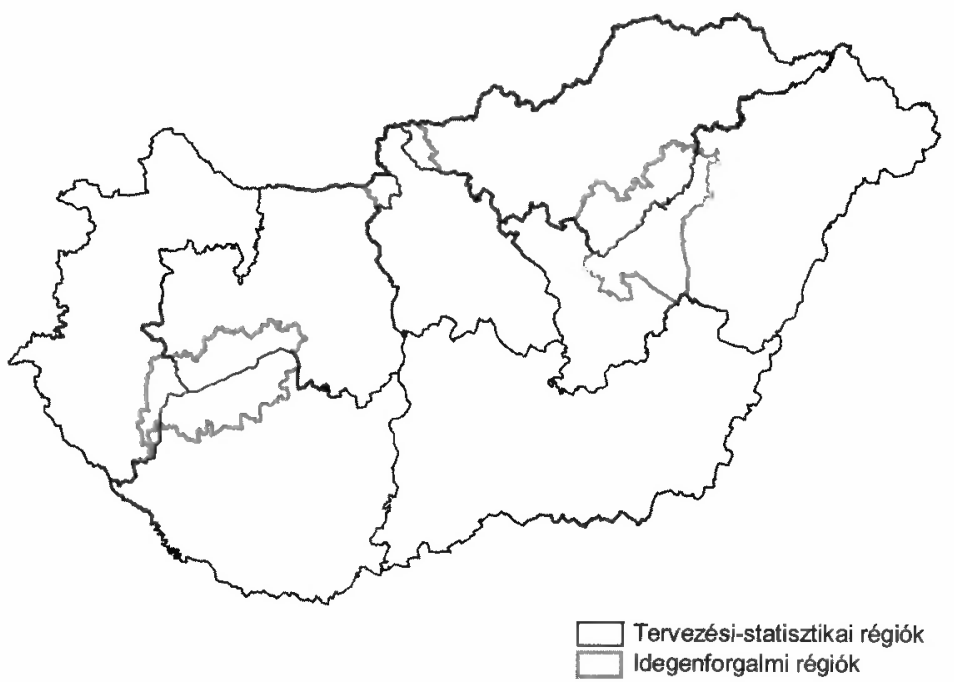

Forrás: Saját szerkesztés.

$\mathrm{Az}$ elérhetőség és az idegenforgalom problémakörének vizsgálata előtt természetesen meg kell, jegyezzük, hogy a turisztikai desztinációk térbeli elhelyezkedése sok esetben Magyarországon (pl. gyógyfürdők, gyógyhelyek) nem köthető a legjelentősebb közúti közlekedési folyosókhoz, mivel azok elsősorban a legjelentösebb népességú és gazdasági potenciálú településeket kötik össze. További problémát jelent még a szervezett idegenforgalom szélsőséges koncentrációja. A 3167 településből csak mintegy 700-on van szervezett idegenforgalom (kereskedelmi szálláshely), míg a bevételek 78\%-a a legjobb 30 település között oszlik meg.

Az elérhetőségi viszonyokat a települések közúthálózathoz való viszonya alapján a 2007. január 1-jei állapotnak megfelelően modelleztük. Magyarország településeit négy elérhetőségi csoportba soroltuk: az 1) csoportba az autópályáktól $10 \mathrm{~km}$-en belül elhelyezkedő, a 2) csoportba az autóutaktól és az elsőrendú föútvonalaktól $10 \mathrm{~km}$-en belül elhelyezkedö, a 3) csoportba a másodlagos föútvonalaktól $10 \mathrm{~km}$-en belül elhelyezkedő, végül a 4) csoportba a fennmaradó települések kerültek (3. ábra).

Ahol nincs desztináció, mert nincs turisztikai vonzerő, ott egy esetleges infrastrukturális beruházás hatására sem lesz. Vizsgálatunk elsősorban arra vonatkozik, hogy ha van turisztikai vonzerő, akkor a desztinációk bevételei mennyire függnek a közúthálózattól és a helyi viszonyoktól.

Feltesszük hipotézisként, hogy a közúti elérhetőség és az idegenforgalmi bevételek (jelesül a kereskedelmi szálláshelyek szállásdíj-bevételei) nagysága között létezhet összefüggés, elemzésünkben ennek nagyságát és összetevőit kívántuk elemezni loglineáris modell segítségével. 
Tóth Géza - Dávid Lóránt : Az elérhetőség és az idegenforgalom kapcsolata.

Tér és Társadalom 23. évf. 2009/3. 45-62. p.

\section{3. ÁBRA}

Magyarország települései a közúthálózat függvényében, 2007

(The Settlements of Hungary as a Function of the Public Road Network, 2007)

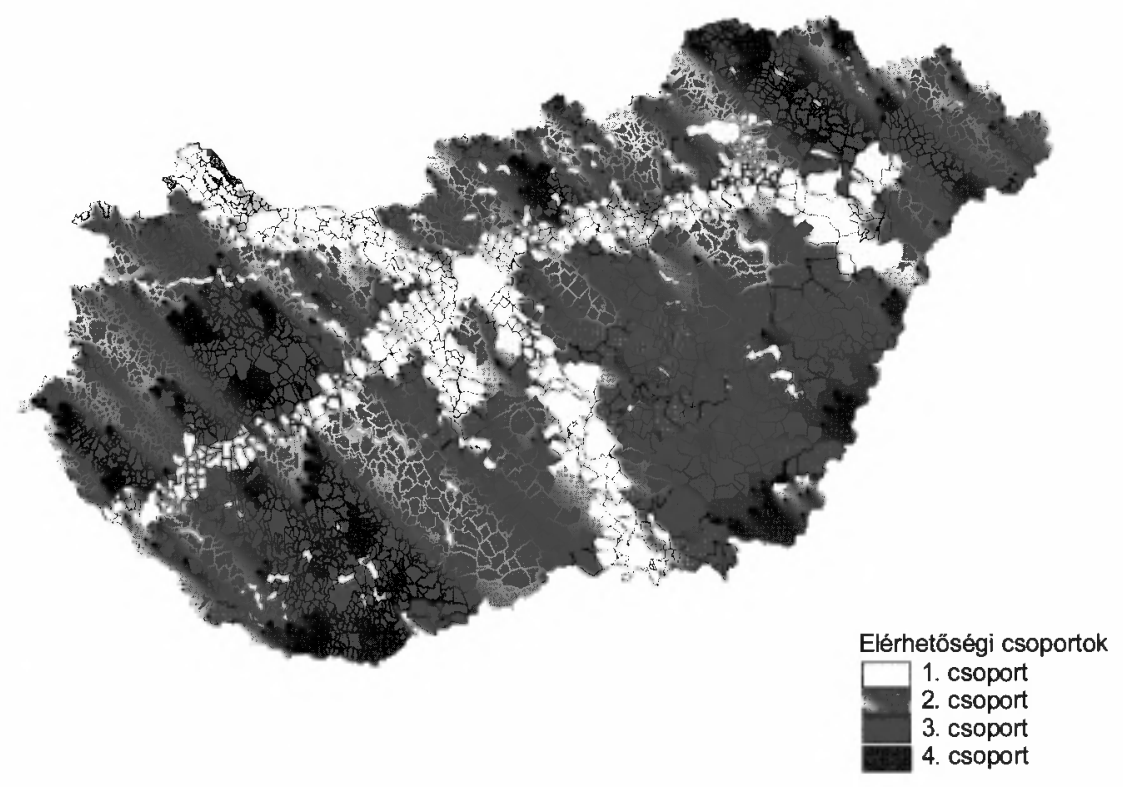

Forrás: Saját szerkesztés.

\section{Loglineáris elméleti modell}

A loglineáris modell azt vizsgálja meg, hogy mikor és milyen értelemben függetlenek egymástól változóink. A módszer úgy értelmezi a változók közötti kapcsolatot, hogy amennyiben az egyik esemény egyik ismérve szerint egyik kategóriába esik, akkor ez valószínüvé teszi ugyanennek a megfigyelésnek a másik jellemzője szerint bizonyos kategóriába esését. Az ilyen jellegủ hozzárendelést a változók közötti kölcsönhatásnak (interakciónak) szokták nevezni (Füstös 1985).

Ehhez induljuk ki egy általános kontingencia táblázatból (1., 2. táblázat). Mivel a Dél-dunántúli idegenforgalmi régióban jelenleg nincs olyan település, melyet az 1) elérhetőségi csoportba sorolhatnánk, így - módszertani okokból - a hiányzó adatot pótolni kellett. A pótlást a kontingencia-táblázat minimumértékeinek az üres cellába való helyezésével értük el.

Legyen X, Y két (valószínűségi) változó, I illetve J elemủ értékkészlettel, ahol:

$\mathrm{p}_{\mathrm{ij}}=\mathrm{P}\left(\mathrm{X}=\mathrm{x}_{\mathrm{i}}, \mathrm{Y}=\mathrm{y}_{\mathrm{j}}\right)$.

Jelölje $m_{i j}=n * p_{i j}-t$, azaz $m_{i j}$ a kontigencia táblázatunk általános eleme, továbbá legyen $\xi_{\mathrm{ij}}=\log \left(\mathrm{m}_{\mathrm{ij}}\right)$. 
Tóth Géza - Dávid Lóránt : Az elérhetőség és az idegenforgalom kapcsolata.

Tér és Társadalom 23. évf. 2009/3. 45-62. p.

TÉT XXIII. évf. 2009 a 3 Az elérhetöség és az idegenforgalom... 51

A kontingencia-táblázat minden egyes elemének a logaritmusát véve elóáll egy 乌̧-táblázat, vagy más megközelítésben a mátrix.

A szokásos jelölés szerint a táblázat tetszőleges sorának, oszlopának, illetve a teljes táblázat átlagának kiszámítását a következő képletek írják le:

$$
\xi_{i *}=\frac{\sum_{j} \xi_{i j}}{J}, \quad \xi_{* j}=\frac{\sum_{i} \xi_{i j}}{I}, \xi_{* *}=\frac{\sum_{i} \sum_{j} \xi_{i j}}{I \cdot J}
$$

Tehát az eredeti táblázatunk logaritmusait tartalmazó ủj táblázat tetszőleges elemét felírhatjuk az alábbi alakban:

$$
\xi_{i j}=\xi_{* *}+\left(\xi_{i *}-\xi_{* *}\right)+\left(\xi_{* j}-\xi_{* *}\right)+\left[\xi_{i j}-\left(\xi_{i *}-\xi_{* *}\right)-\left(\xi_{* j}-\xi_{* *}\right)-\xi_{* *}\right\rfloor
$$

Ezt úgy interpretálhatjuk, hogy bármely tetszöleges elem elöáll a teljes átlag, az adott sornak megfelelỏ átlag, az adott oszlopnak megfelelö átlag, valamint a megfelelő sor-oszlop kölcsönhatás (interakció) összegeként.

Ahol $m_{i j}$ tényleges esetszám az i-j cellában, I idegenforgalmi régió ( $i=9$ ), $J$ elérhetőségi kategória ( $\mathrm{j}=4$ ) (3. ábra), $\xi_{\mathrm{i} *}$ az i-edik idegenforgalmi régióra belföldi, illetve külföldi szállásdíj-bevételek logaritmusa a különböző elérhetőségi csoportok szerint, $\xi_{*_{j}}$ a j-edik elérhetőségi csoportra jutó belföldi, illetve külföldi szállásdíjbevételek logaritmusa az idegenforgalmi régiók szerint, $\xi_{\mathrm{ij}}$ annak valószínüsége, hogy a megfigyelt külföldi vagy belföldi szállásdíj-bevétel tábla ij-edik cellájába esik, az összes előbbi alsórendü paraméter által meghatározott valószínüségekhez viszonyítva.

Az elózö összefüggésbe a $\xi_{\mathrm{ij}}=\log \left(\mathrm{m}_{\mathrm{ij}}\right)-\mathrm{t}$ helyettesítve egy additív formához jutunk:

$$
\begin{aligned}
& \log m_{i j}=\mu+\lambda_{i}^{x}+\lambda_{j}^{y}+\lambda_{i j}^{x y} \\
& m_{i j}=e^{\mu} \cdot e^{\lambda_{i}^{x}} \cdot e^{\lambda_{j}^{y}} \cdot e^{\lambda_{i j}^{x y}}
\end{aligned}
$$

Ahol $\mu$-vel jelöltük a teljes átlagot, az i-indexü $\lambda$-val a sorhatást, a j-indexủvel az oszlophatást, míg az ij indexszel a kölcsönhatást.

Ennek a felbontásnak nagy előnyeit a következő képletek mutatják meg, azaz olyan felbontást eszközöltünk, melyben a sor-oszlophatások, illetve az interakciók egész táblázatra nézve nullát adnak ki, más szavakkal egész táblázatra vett hatásuk zéró:

$$
\begin{aligned}
& \sum_{i} \lambda_{i}^{x}=\sum_{j} \lambda_{j}^{y}=0 \quad\left(\prod e^{\lambda_{i}^{x}}=1\right) \\
& \sum_{i} \lambda_{i j}^{x y}=\sum_{j} \lambda_{i j}^{x y}=0
\end{aligned}
$$


Tóth Géza - Dávid Lóránt : Az elérhetőség és az idegenforgalom kapcsolata.

Tér és Társadalom 23. évf. 2009/3. 45-62. p.

\section{TÁBLÁZAT}

Kereskedelmi szálláshelyek belföldi szállásdijj-bevételének megoszlása (\%), 2007 (The Share of Domestic Incomes of Public Accommodation Establishments in 2007 [\%])

\begin{tabular}{|c|c|c|c|c|c|c|c|c|c|c|}
\hline \multirow[b]{2}{*}{$\begin{array}{l}\text { Elérhe- } \\
\text { töségi } \\
\text { csopor- } \\
\text { tok }\end{array}$} & \multicolumn{9}{|c|}{ Idegenforgalmi régiók } & \multirow[b]{2}{*}{$\begin{array}{c}\text { Össze- } \\
\text { sen }\end{array}$} \\
\hline & $\begin{array}{c}\text { Buda- } \\
\text { pest- } \\
\text { Közép- } \\
\text { dunavi- } \\
\text { déki }\end{array}$ & $\begin{array}{c}\text { Észak- } \\
\text { magyar } \\
\text { or- } \\
\text { szági }\end{array}$ & $\begin{array}{l}\text { Eszak- } \\
\text { alföldi }\end{array}$ & $\begin{array}{c}\text { Tisza- } \\
\text { tovi }\end{array}$ & $\begin{array}{c}\text { Dél- } \\
\text { alföldi }\end{array}$ & $\begin{array}{l}\text { Közép- } \\
\text { dunán- } \\
\text { túli }\end{array}$ & $\begin{array}{c}\text { Bala- } \\
\text { toni }\end{array}$ & $\begin{array}{l}\text { Dél- } \\
\text { dunán- } \\
\text { túli }\end{array}$ & $\begin{array}{l}\text { Nyugat- } \\
\text { dunán- } \\
\text { túli }\end{array}$ & \\
\hline $\begin{array}{l}\text { 1. cso- } \\
\text { port }\end{array}$ & 14,1 & 3,4 & 3,7 & 0,2 & 3 & 2,5 & 12,9 & - & 1,8 & 41,6 \\
\hline $\begin{array}{l}\text { 2. cso- } \\
\text { port }\end{array}$ & 1,7 & 0,5 & 6,2 & 0,0 & 2,5 & 1,3 & 5,7 & 3,3 & 0,5 & 21,7 \\
\hline $\begin{array}{l}\text { 3. cso- } \\
\text { port }\end{array}$ & 2,8 & 6,1 & 0,7 & 0,3 & 1,2 & 1,5 & 6 & 2,2 & 10,2 & 0 \\
\hline $\begin{array}{c}\text { 4. cso- } \\
\text { port }\end{array}$ & 0,3 & 1,9 & 0 & 0,6 & 0,3 & '2 & 0,0 & 0,8 & (5) & 4,7 \\
\hline $\begin{array}{c}\text { Össze- } \\
\text { sen }\end{array}$ & 18,9 & 11,9 & 10,7 & 1,1 & 7,1 & 5,6 & 25,5 & 6,3 & 12,9 & 100,0 \\
\hline
\end{tabular}

Forrás: KSH adatok alapján saját számítás.

Loglineáris modell segítségével analizáltuk a két esetet (a belföldi és a külföldi bevételek területi eloszlását). Null-hipotézisünk az volt, hogy adataink függetlenek, azaz nincsen interakció a két változónk között sem a külföldi, sem a belföldi szállásdij-bevételek között.. E hipotézis szerint a telitett modell (összes interakciót tartalmazza, azaz itt az elérhetőség-régió kölcsönhatást) és a kölcsönhatás nélküli modell jól illeszkednek egymáshoz. Jelöljük A-val az idegenforgalmi régiókat, B-vel az elérhetőségi csoportokat.

\section{TÁBLÁZAT}

Kereskedelmi szálláshelyek külföldi szállásdijj-bevételének megoszlása (\%), 2007

(The Share of International Incomes of Public Accommodation Establishments, $2007[\%])$

\begin{tabular}{|c|c|c|c|c|c|c|c|c|c|c|}
\hline \multirow[b]{2}{*}{$\begin{array}{c}\text { Elérhe- } \\
\text { tôségi } \\
\text { csopor- } \\
\text { tok }\end{array}$} & \multicolumn{9}{|c|}{ Idegenforgalmi régiók } & \multirow[b]{2}{*}{$\begin{array}{c}\text { Össze- } \\
\text { sen }\end{array}$} \\
\hline & $\begin{array}{l}\text { Buda- } \\
\text { pest- } \\
\text { Közép- } \\
\text { duna- } \\
\text { vidéki }\end{array}$ & $\begin{array}{c}\text { Észak- } \\
\text { magyar } \\
\text { or- } \\
\text { szági }\end{array}$ & $\begin{array}{l}\text { Észak- } \\
\text { alföldi }\end{array}$ & $\begin{array}{c}\text { Tisza- } \\
\text { tavi }\end{array}$ & $\begin{array}{l}\text { Dél- } \\
\text { alföldi }\end{array}$ & $\begin{array}{l}\text { Közép- } \\
\text { dunán- } \\
\text { túli }\end{array}$ & $\begin{array}{c}\text { Balato- } \\
n i\end{array}$ & $\begin{array}{c}\text { Dél- } \\
\text { dunán- } \\
\text { túli }\end{array}$ & $\begin{array}{c}\text { Nyugat- } \\
\text { dunán- } \\
\text { túli }\end{array}$ & \\
\hline $\begin{array}{c}\text { 1. cso- } \\
\text { port }\end{array}$ & 75,5 & 0,6 & 0,9 & 0 , & 1,0 & 1,7 & 2,7 & - & 1,7 & 84,1 \\
\hline $\begin{array}{c}\text { 2.csopor } \\
t\end{array}$ & 0,4 & 0,0 & 1,8 & 0,0 & 0,2 & 0,4 & 2,0 & 0,7 & 0,1 & 5,6 \\
\hline $\begin{array}{c}\text { 3. cso- } \\
\text { port }\end{array}$ & 0,1 & 0,8 & 0,2 & 0,0 & 0,3 & 0,3 & 4,2 & 0,5 & 3,6 & 10,1 \\
\hline $\begin{array}{l}\text { 4. cso- } \\
\text { port }\end{array}$ & 0,0 & 0,0 & 0,0 & 0,0 & 0,1 & 0,0 & 0 & 0,1 & 0 & 0,2 \\
\hline $\begin{array}{c}\text { Össze- } \\
\text { sen }\end{array}$ & 76,1 & 1,5 & 2,8 & 0,2 & 1,6 & 2,3 & 8.9 & 1,3 & 5,4 & 100,0 \\
\hline
\end{tabular}

Forrás: KSH adatok alapján saját számítás. 
Tóth Géza - Dávid Lóránt : Az elérhetőség és az idegenforgalom kapcsolata.

Tér és Társadalom 23. évf. 2009/3. 45-62. p.

TÉT XXIII. évf. 2009 - 3 Az elérhetöség és az idegenforgalom... 53

\section{A loglineáris modell eredményei}

A kritikus $\chi^{2}$ érték (95\%-os szinthez) 5,99; az adataink ettől nagyságrendekkel magasabb értéket adtak, így mivel nem illeszkednek a kölcsönhatások elhagyásával kapott értékek az eredeti kontingencia táblázathoz, a null-hipotézist elvetjük. Más szavakkal az idegenforgalmi régiók és az elérhetőségi csoportok a magyar-külföldi bevételekkel való összehasonlításban nem függetlenek egymástól, a valós adatokat a két változó közötti interakció elhagyásával nem tudjuk magyarázni.

Célunk a továbbiakban annak kiderítése, hogy milyen kimutatható, számszerü hatása van a régióknak, illetve az elérhetőségnek a kereskedelmi szálláshelyek magyar-külfoöldi szállásdíj árbevételére.

A vizsgálatunkat a 2007 -es évre végeztünk el. Az e értékei a belföldi bevétel szerinti táblázatnál: 530762 , míg a külföldinél: 122 542. A további táblázatba (4. táblázat) a megfelelö kölcsönhatások e-edik hatványai kerültek. Így a fenti $\mathrm{e}^{\mu}$ értékekkel és a kiszámolt táblázattal elő tudjuk állítani az előző táblázatok alapadatait (1., 2. táblázat).

Például a Budapest-Közép-dunavidéki idegenforgalmi régió első elérhetőségi csoportba tartozó településeinek magyar szállásdíj-bevételeit megkaphatjuk, ha a fenti 530 762-t a következő táblázat Budapest-Közép-dunavidéki hatásával $(1,96)$, az elsô csoport hatásával $(1,63)$ és a kettó közötti interakcióval $(4,14)$ összeszorozzuk. Ekkor 7014 637-et kapunk (ami a megfelelő táblázat első sorának alapadata). Hasonlóan kapjuk meg a többi cellaértéket is.

Az eredmények önmagukban képesek informálni arról (3. táblázat), hogy 1-1 változó, változók közötti kapcsolatok milyen módon befolyásolják az árbevételeket. Az 1-nél nagyobb értékek növekvőleg hatnak a bevételekre, az 1-nél kisebbek csökkentik azt.

Ezek alapján azt tudjuk mondani, hogy az elérhetőség növekedése és a bevételek növekedése között nincs feltétlen kapcsolat. Igaz ugyan, hogy a legkedvezőbb elérhetőségủ területeken (első elérhetőségi csoport) egyben a legmagasabb kölcsönhatási értéket láthatjuk, de a belföldi bevételeknél a legkedvezőbb értéket mégis a 3) csoportnál figyelhetjük meg. A külföldi bevételeknél szintén az elsőben látjuk a legmagasabb értéket, viszont ezután a 2) csoport kölcsönhatási értéke alacsonyabb, mint a harmadiké. Összegezve, nem lehet egyértelmủ kapcsolatot találni a települések elérhetőségi helyzete és az idegenforgalmi bevételek nagysága között. 
Tóth Géza - Dávid Lóránt : Az elérhetőség és az idegenforgalom kapcsolata.

Tér és Társadalom 23. évf. 2009/3. 45-62. p.

\begin{tabular}{|c|c|c|c|}
\hline & \multicolumn{2}{|c|}{$\begin{array}{l}\text { 3. TÁBLÁZAT } \\
\text { A loglineáris elemzés eredménytáblája } \\
\text { (Results of the Loglinear Analysis) }\end{array}$} & \multirow[b]{2}{*}{ Külföldi bevétel } \\
\hline & Paraméter & Belföldi bevétel & \\
\hline \multirow{9}{*}{ Régió } & Budapest-Közép-dunavidéki & 1,96 & 18,59 \\
\hline & Észak-magyarországi & 1,97 & 0,65 \\
\hline & Észak-alfơldi & 0,95 & 0,69 \\
\hline & Tisza-tavi & 0,16 & 0,61 \\
\hline & Dél-alfơldi & 1,24 & 0.65 \\
\hline & Közép-dunántúli & 0,98 & 0,67 \\
\hline & Balatoni & 1,80 & 0,91 \\
\hline & Dél-dunántúli & 0,56 & 0,64 \\
\hline & Nyugat-dunántủli & 1,38 & 0,77 \\
\hline \multirow{4}{*}{ Elérhetỏség } & 1. csoport & 1,63 & 3,26 \\
\hline & 2. csoport & 1,09 & 0,68 \\
\hline & 3. csoport & 2,06 & 0,74 \\
\hline & 4. csoport & 0,27 & 0,61 \\
\hline \multirow{35}{*}{$\begin{array}{l}\text { Régió- } \\
\text { Elérhetöség }\end{array}$} & Budapest-Közép-dunavidéki -1 . csoport & 4,14 & 8011,23 \\
\hline & Budapest-Közép-dunavidéki -2 . csoport & 0,76 & 0,05 \\
\hline & Budapest-Közép-dunavidéki - 3. csoport & 0,66 & 0,05 \\
\hline & Budapest-Közép-dunavidéki - 4. csoport & 0,48 & 0,05 \\
\hline & Észak-magyarországi - 1. csoport & 0,99 & 0,32 \\
\hline & Észak-magyarországi -2 . csoport & 0,22 & 1,39 \\
\hline & Észak-magyarországi - 3. csoport & 1,42 & 1,46 \\
\hline & Észak-magyarországi -4 . csoport & 3,28 & 1,55 \\
\hline & Észak-alföldi - 1. csoport & 2,26 & 0,32 \\
\hline & Észak-alföldi - 2. csoport & 5,63 & 1,78 \\
\hline & Észak-alföldi -3 . csoport & 0,35 & 1,23 \\
\hline & Észak-alföldi - 4. csoport & 0,22 & 1,44 \\
\hline & Tisza-tavi - 1. csoport & 0,79 & 0,31 \\
\hline & Tisza-tavi -2 . csoport & 0,11 & 1,46 \\
\hline & Tisza-tavi - 3. csoport & 0,94 & 1,34 \\
\hline & Tisza-tavi - 4. csoport & 11,99 & 1,64 \\
\hline & Dél-alföldi - 1. csoport & 1,41 & 0,34 \\
\hline & Dél-alföldi -2 . csoport & 1,72 & 1,43 \\
\hline & Dél-alfôldi - 3. csoport & 0,44 & 1,33 \\
\hline & Dél-alföldi -4 . csoport & 0,93 & 1,54 \\
\hline & Közép-dunántúli - 1. csoport & 1,47 & 0,37 \\
\hline & Közép-dunántúli - 2. csoport & 1,19 & 1,42 \\
\hline & Közép-dunántúli - 3. csoport & 0,69 & 1,28 \\
\hline & Közép-dunántúli - 4. csoport & 0,83 & 1,48 \\
\hline & Balatoni - 1. csoport & 4,11 & 0,33 \\
\hline & Balatoni -2 . csoport & 2,73 & 1,42 \\
\hline & $\begin{array}{l}\text { Balatoni - 3. csoport } \\
\text { Balatoni - 4. csoport }\end{array}$ & $\begin{array}{l}1,75 \\
0,05\end{array}$ & $\begin{array}{l}1,94 \\
1,10\end{array}$ \\
\hline & Dél-dunántúli - 1. csoport & 0,02 & 0,29 \\
\hline & Dél-dunántúli -2 . csoport & 5,04 & 1,58 \\
\hline & Dél-dunántúli - 3. csoport & 1,79 & 1,40 \\
\hline & Dél-dunántúli - 4. csoport & 5,14 & 1,57 \\
\hline & Nyugat-dunántúli - 1. csoport & 0,74 & 0,33 \\
\hline & Nyugat-dunántúli - 1. csoport & 0,34 & 1,18 \\
\hline & Nyugat-dunántúli -3 . csoport & 3,37 & 2,01 \\
\hline & Nyugat-dunántúli -4 . csoport & 1,17 & 1,29 \\
\hline
\end{tabular}

Forrás: Saját szerkesztés. 
Tóth Géza - Dávid Lóránt : Az elérhetőség és az idegenforgalom kapcsolata.

Tér és Társadalom 23. évf. 2009/3. 45-62. p.

A külföldi és belföldi bevételek között jelentős a különbség abban a vonatkozásban, hogy a legjobb elérhetőségú helyzetben mekkora a szorzó nagysága. Mivel a legjobb elérhetőségủ településeken a külföldi bevételek szorzója jóval magasabb, mint a belföldieké, megállapíthatjuk, hogy a külföldi bevételek jóval érzékenyebbek a kedvező elérhetőségi helyzetre, mint a belföldiek.

A régiós interakciók lényegében tükrözik a bevételek közötti területi különbségeket. Érdemes viszont megfigyelni a külföldi és a belföldi bevétel közötti nagy kölcsönhatási különbségeket, melynek oka elsősorban a külföldi bevételek igen erős területi koncentrációját mutatja, míg ehhez képest a belföldieknél jóval egyenletesebb az eloszlás (4. ábra).

\section{4. ÁBRA \\ A régiós interakciók nagysága a belföldi és a külföldi szállásdij-bevételek vonatkozásában, 2007}

(The Rate of Regional Interactions in Respect of the Domestic and International Incomes from Accommodation Fees, 2007)

belföldi külföldi

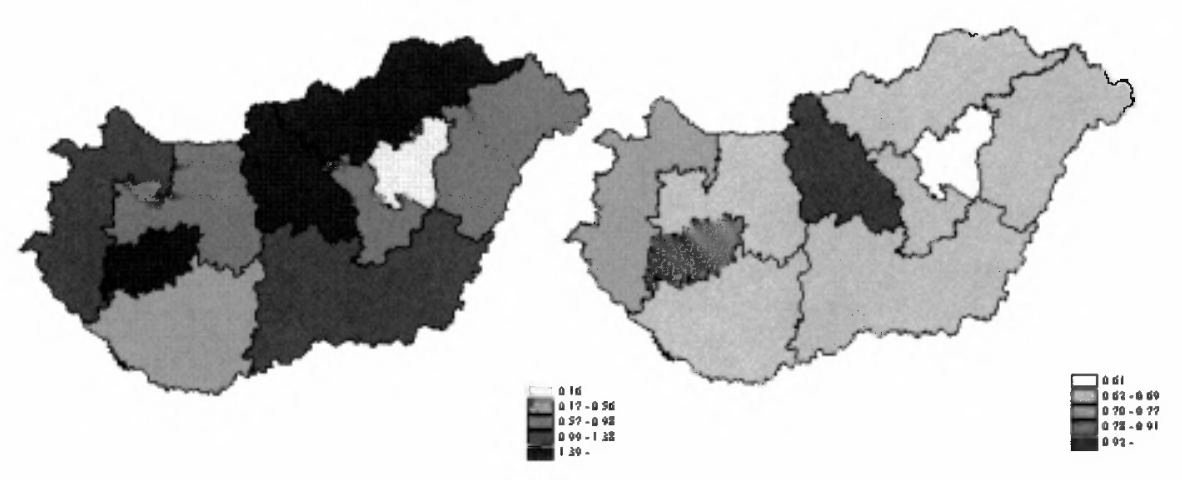

Forrás: Saját szerkesztés.

Változóink azonban nemcsak egyenként, függetlenül fejtik ki hatásukat az árbevételekre, hanem egymással kölcsönhatásban is. Ekkor válik láthatóvá a tábláinkból és a belölük készített ábrákból (5., 6. ábra), hogy belföldi bevételekre az elsỏ csoport által érintett települések közül elsősorban a Budapest-Közép-dunavidéki régióban zárójelben a településcsoport legjelentősebb bevételủ települése/i - (Budapest Ráckeve), a második csoportnál viszont az Észak-alföldi régióban (Hajdúszoboszló, Szolnok) legjelentősebb a szorzó. A harmadik csoport kedvező hatása leginkább a Nyugat-dunántúli régióban (Sopron, Bük), míg a negyediké a Tisza-tavi régióban (Berekfürdő, Kisköre) érzékelhető. 
Tóth Géza - Dávid Lóránt : Az elérhetőség és az idegenforgalom kapcsolata.

Tér és Társadalom 23. évf. 2009/3. 45-62. p.

A külfơldi bevételeknél annyi eltérést láthatunk, hogy bár minden csoportnál abban az idegenforgalmi régióban a legnagyobb a szorzó, mint a belföldi bevételeknél, viszont mértéke eltér attól. Az első csoportnál a külföldi bevételeknél látható szorzó mértéke majd 2000-szerese a belföldi szállásdij-bevételeknél megfigyelhetönek! Ez a magyarországi külföldi bevételek igen erös területi, illetve elérhetőségi szempontú koncentrálódására utal. A másik három csoportban viszont a szorzó némileg alacsonyabb a belföldieknél láthatóhoz képest, vagyis a kevésbé jó elérhetöségi helyzet már kevésbé ad lehetőséget a külföldi bevételek területi koncentrációjára.

\section{5. ÁBRA}

Az idegenforgalmi régiók és az elérhetöségi csoportok közötti interakciók a belföldi szállásdij-bevételeknél, 2007

(Interactions between Tourism Regions and Accessibility Groups in the Case of Domestic Incomes from Accommodation Fees, 2007)

\section{1. csoport}

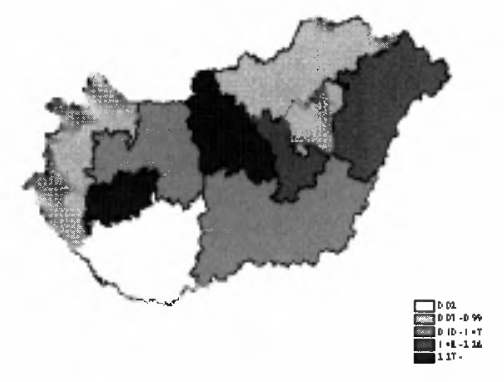

3. csoport

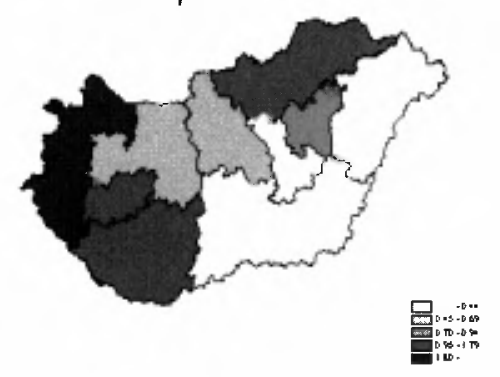

2. csoport

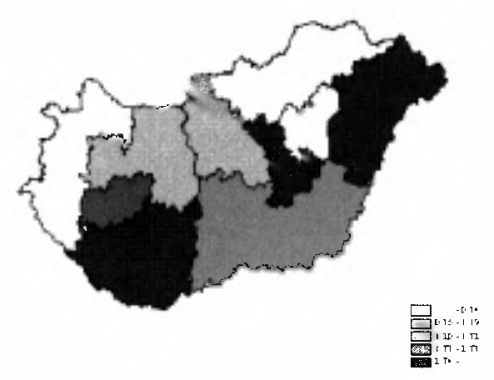

4. csoport

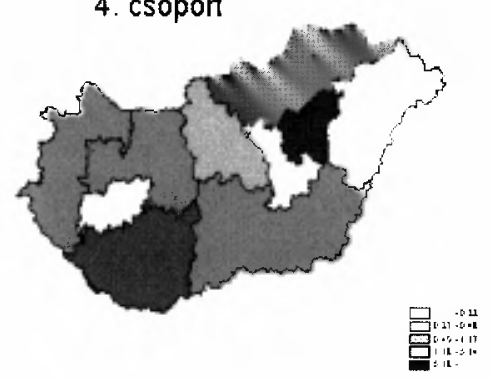

Forrás: Saját szerkesztés. 
Tóth Géza - Dávid Lóránt : Az elérhetőség és az idegenforgalom kapcsolata.

Tér és Társadalom 23. évf. 2009/3. 45-62. p.

\section{6. ÁBRA}

Az idegenforgalmi régiók és az elérhetőségi csoportok közötti interakciók a külföldi szállásdij-bevételeknél, 2007

(Interactions between Tourism Regions and Accessibility Groups in the Case of International Incomes from Accommodation Fees, 2007)

1. csoport

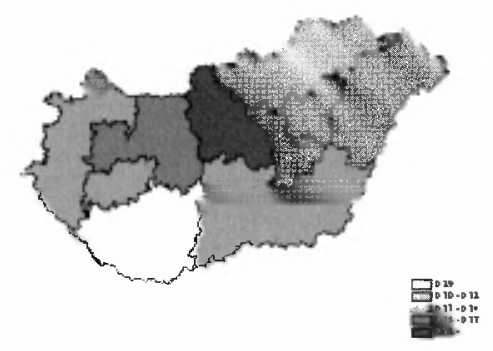

3. csoport

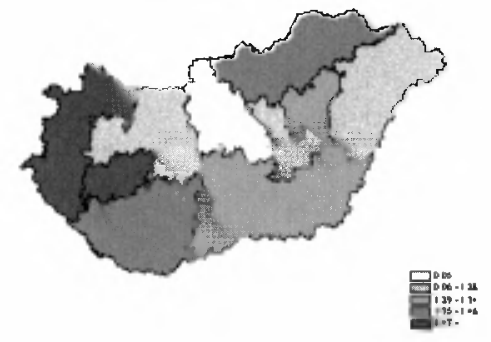

2. csoport

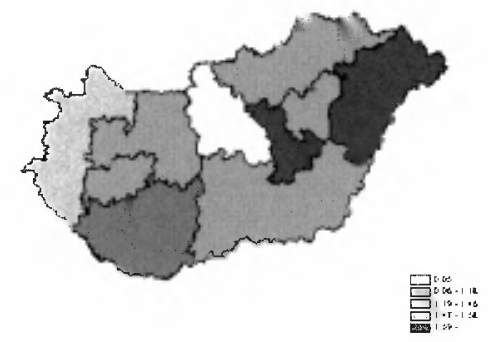

4. csoport

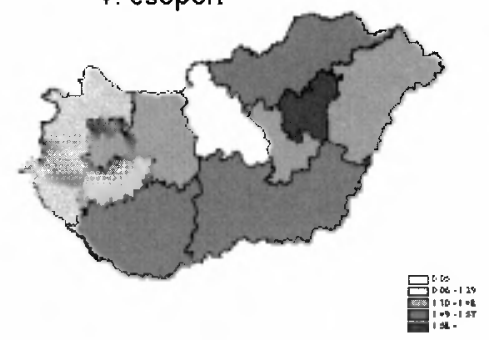

Forrás: Saját szerkesztés.

\section{A magyarországi belföldi turisztikai áramlások vizsgálata}

A következőkben azt igyekeztünk megvizsgálni, hogy a turizmus tekintetében kiszámítható elméleti elérhetóségi viszonyok, illetve a valódi belföldi mozgások között milyen kapcsolatot lehet feltárni. Ebben a vizsgálatban a többnapos belföldi utazások számát az egyes régiókból célrégió szerint próbáltuk összevetni a gravitációs modellel megbecsült „elméleti” mozgások nagyságával.

Az alapadat a KSH Lakosság utazási szokásai (LUSZ) nevü felméréséböl származik, melynek 12 ezres reprezentatív mintája választ ad a lakosság turisztikai utazási szokásainak leglényegesebb kérdéseire.

A lakosság turisztikai aktivitásával kapesolatban megállapítható, hogy a turizmusnak az életminőség formálásában, a rekreációban, az értékteremtésben még jelentös tartalékai lehetnek Magyarországon. 2007-ben a magyar lakosságnak - az éjszakázással nem járó „kirándulások” nélkül - csak $42 \%$-a vett részt a belföldi idegenforgalomban, azaz legalább egy alkalommal tett többnapos belföldi utazást. 
Tóth Géza - Dávid Lóránt : Az elérhetőség és az idegenforgalom kapcsolata.

Tér és Társadalom 23. évf. 2009/3. 45-62. p.

A 2004 és 2006 közötti időszakban nött a lakosság utazási aktivitása, az utazások száma és az utazásra fordított szabadidő, folyó áron 37\%-kal emelkedett az utazásra fordított fogyasztási kiadás. Ezt követően 2007-ben csökkent az aktivitás, csökkent az utazások száma, nőtt az erre fordított idő (106 millió napra), és folyó áron 11\%-kal bővült a fogyasztás egy év alatt ( $K S H$ 2008).

Vizsgálatunkban ezt a csoportot, illetve mozgásukat igyekeztünk górcső alá venni.

\section{TÁBLÁZAT}

Többnapos belföldi utazások megoszlása az egyes régiókból célrégió szerint, 2007 (\%) (The Distribution of Multi-day Domestic Travels from the Given Regions According to Target Regions in 2007 [\%])

\begin{tabular}{|c|c|c|c|c|c|c|c|c|c|c|c|}
\hline & \multicolumn{9}{|c|}{ Idegenforgalmi régiók } & \multirow[b]{2}{*}{$\begin{array}{l}\ddot{O}_{s z} \\
\text { sze- } \\
\text { sen }\end{array}$} \\
\hline & & $\begin{array}{c}\text { Buda- } \\
\text { pest } \\
\text { Kö- } \\
\text { zép- } \\
\text { Duna- } \\
\text { vidék }\end{array}$ & $\begin{array}{c}\text { Észak- } \\
\text { Ma- } \\
\text { gyar- } \\
\text { ország }\end{array}$ & $\begin{array}{c}\text { Eszak } \\
- \\
\text { Alföld }\end{array}$ & $\begin{array}{l}T i- \\
\text { sza- } \\
\text { tavi }\end{array}$ & $\begin{array}{c}\text { Dél- } \\
\text { alfól- } \\
\text { di }\end{array}$ & $\begin{array}{l}\text { Közép- } \\
\text { dunán- } \\
\text { túli }\end{array}$ & $\begin{array}{c}\text { Balato } \\
-n i\end{array}$ & $\begin{array}{l}\text { Dél- } \\
\text { dunán- } \\
\text { túli }\end{array}$ & $\begin{array}{c}\text { Nyu- } \\
\text { gat- } \\
\text { dunán- } \\
\text { túli }\end{array}$ & \\
\hline \multirow{7}{*}{ 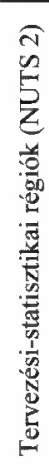 } & $\begin{array}{l}\text { Közép- } \\
\text { Magyar- } \\
\text { ország }\end{array}$ & 31,9 & 10,5 & 8,0 & 1,1 & 7,7 & 10,4 & 19,2 & 4,6 & 6,7 & 100 \\
\hline & $\begin{array}{l}\text { Közép- } \\
\text { Dunántúl }\end{array}$ & 16,3 & 3,9 & 5,0 & 0,3 & 6,3 & 28,1 & 25,3 & 6,4 & 8,5 & 100 \\
\hline & $\begin{array}{l}\text { Nyugat- } \\
\text { Dunántúl }\end{array}$ & 13,6 & 2,7 & 3,2 & - & 2,4 & 10,3 & 28,8 & 3,7 & 35,3 & 100 \\
\hline & Dél-Dunántúl & 16,3 & 1,6 & 1,5 & 0,2 & 6,7 & 5,8 & 16,3 & 47,1 & 4,4 & 100 \\
\hline & $\begin{array}{l}\text { Észak- } \\
\text { Magyaror- } \\
\text { szág }\end{array}$ & 19,2 & 31,9 & 7,7 & 4,6 & 8,0 & 10,5 & 10,4 & 6,7 & 1,1 & 100 \\
\hline & Észak-Alföld & 13,3 & 13,1 & 56,3 & 4,5 & 5,5 & 1,2 & 4,0 & 0,8 & 1,3 & 100 \\
\hline & Dél-Alföld & 16,1 & 5,8 & 7,4 & 1,4 & 47,3 & 4,1 & 11,3 & 4,0 & 2,7 & 100 \\
\hline
\end{tabular}

Forrás: KSH adatok alapján saját számítás.

Az elméleti mozgásokat gravitációs modellel próbáltuk modellezni. A gravitációs törvény szerint két test közötti vonzóerő nagysága a két test tömegével $\left(P_{i}\right.$ és $\left.P_{j}\right)$ egyenesen, a közöttük levő távolság $\left(\mathrm{d}_{\mathrm{ij}}\right)$ négyzetével fordítottan arányos (Stewart 1948; Isard et al. 1998).

$D_{i j}=g\left(\frac{P_{i} P_{j}}{d_{i j}^{\gamma}}\right)$

ahol $\mathrm{D}_{\mathrm{ij}}$ a modell alapján várt áramlás i-ből $\mathrm{j}$-be; $\mathrm{P}_{\mathrm{i}}$ települések népessége, ahonnan turisztikai célból utazhatnak (az összes magyarországi település ilyen); $P_{\mathrm{j}}$ azon települések kereskedelmi és magánszálláshelyein megszállt vendégek száma, ahova turisztikai célból utazhatnak (csak azon települések kerültek ebbe a körbe, ahol van kereskedelmi vagy magánszálláshely); $\boldsymbol{d}_{\mathrm{ij}}$ a települések közötti távolság közúton, percben; $\gamma$ állandó; $g$ konstans, jelen esetben 1. 
A modellben annak ellenére a teljes népességgel számoltunk, hogy a valóságban nem valószínủ, hogy mindenki részt vesz a turisztikai áramlásokban. A turisztikai tevékenység véghezvitelében jelentős különbségek lehetnek kor, nem, anyagi helyzet, családi állapot és még sok más szempont alapján. Azzal viszont, hogy az össznépesség, mint potenciális turista bekerült a modellbe, egy elméleti maximumot határoztunk meg, melyhez jól mérhetjük a valós áramlások nagyságát és területi megoszlását.

Az elméleti mozgásokat - a vele összehasonlítandó LUSZ-ból származó adatnak megfelelöen - az egyes tervezési-statisztikai régiókból az idegenforgalmi régiókba számítottuk ki, vagyis a mozgásokat a kiinduló tervezési-statisztikai régiók, illetve az érkezési idegenforgalmi régiók szerint összegeztük.

A számítás során fontos volt annak a vizsgálata, hogy a $\gamma$ konstans milyen értéket kapjon. Így számításainkat elvégeztük 1-től 8-ig terjedő konstanssal, és megvizsgáltuk a számított és a valós érték közötti korrelációs kapcsolat szorosságát.

Annak az eldöntésére, hogy végül is melyik konstanst alkalmazó modell írja le legjobban a belföldi turisztikai célú mozgásokat, súlyozott átlagot számítottunk a kapott értékek és a LUSZ-ból származó adatok között, a korrelációs együtthatókat a turisztikai régiókba való összérkezések számával súlyozva, hiszen az egyes régiók szerepe a hazai turisztikai áramlásokban meglehetősen különböző.

\section{TÁBLÁZAT}

Korrelációs együtthatók súlyozott átlagai a gravitációs modell különbözö

$\gamma$ konstansai esetén

(Weighted Averages of the Correlation Coefficients in the Case of Various $\gamma$ Constants of the Gravitation Model)

\begin{tabular}{ccccccccc}
\hline$\gamma$ & 1 & 2 & 3 & 4 & 5 & 6 & 7 & 8 \\
\hline $\mathrm{r}$ & 0,69 & 0,88 & 0,87 & 0,86 & 0,85 & 0,84 & 0,82 & 0,80
\end{tabular}

Forrás: Saját számítás.

Mint az 5. táblázatból is látható, a legmagasabb korrelációs kapcsolat a valós és az elméleti adatok között a távolság négyzete esetében figyelhetô meg. Ettől csak igen kis mértékben marad el a magasabb kitevővel számított modellek értékei és a valós értékek közötti kapcsolat. Mint azt Dusek Tamás gravitációs modellről szóló munkájában megállapítja (Dusek 2003, 47): „A kitevő növekedésével a területközi kapcsolatok intenzitása távolságérzékenyebb lesz, ezzel párhuzamosan a tömegek jelentősége fokozatosan csökken." Mivel a konstansok között csak igen kis különbséget láthatunk, így a belföldi turisztikai áramlások távolság érzékenyeknek tekinthetők.

Végül a számításaink szerint, a turisztikai mozgásokat legjobban leíró - négyzetes konstanst - alkalmazó modell értékeit és a valós értékeket kívántuk összehasonlítani. Ehhez mindkét adatsort standardizáltuk, majd az elméleti értékekből kivontuk a valósokat, s feltárult a kettő közötti különbség.

A kapott értékek előjele csak az elméleti és a valós adatok közötti viszonyra utal, éppen ezért fordul elő az, hogy van olyan régió, ahonnan kiinduló turisztikai áram- 
Tóth Géza - Dávid Lóránt : Az elérhetőség és az idegenforgalom kapcsolata.

Tér és Társadalom 23. évf. 2009/3. 45-62. p.

lások külön-külön minden turisztikai régióba nagyobbak az elméletinél (vagyis negatív előjelet kapott), mégis összességében kisebbek annál.

6. TÁBLÁZAT

Az elméleti és a valós turisztikai áramlások standardizált értékei közötti különbség, 2007 (Differences between the Standardized Values of the Theoretical and Actual Tourist Flows, 2007)

\begin{tabular}{|c|c|c|c|c|c|c|c|c|}
\hline ig tól & $\begin{array}{l}\text { Közép- } \\
\text { Ma- } \\
\text { gyar- } \\
\text { ország }\end{array}$ & $\begin{array}{c}\text { Közép- } \\
\text { Du- } \\
\text { nántúl }\end{array}$ & $\begin{array}{l}\text { Nyu- } \\
\text { gat- } \\
\text { Du- } \\
\text { nántúl }\end{array}$ & $\begin{array}{l}\text { Dél- } \\
\text { Du- } \\
\text { nántúl }\end{array}$ & $\begin{array}{l}\text { Észak- } \\
\text { Ma- } \\
\text { gyar- } \\
\text { ország }\end{array}$ & $\begin{array}{l}\dot{E} \text { szak- } \\
\text { Alföld }\end{array}$ & $\begin{array}{c}\text { Dél- } \\
\text { Alföld }\end{array}$ & $\begin{array}{c}\text { Tervezési- } \\
\text { statiszti- } \\
\text { kai } \\
\text { régiók } \\
\text { összesen }\end{array}$ \\
\hline $\begin{array}{l}\text { Budapest- } \\
\text { Közép- } \\
\text { dunavidéki } \\
\text { régió }\end{array}$ & $-1,38$ & $-0,88$ & $-0,48$ & $-0,41$ & $-0,17$ & $-0,40$ & $-0,50$ & $-2,15$ \\
\hline $\begin{array}{l}\text { Észak- } \\
\text { magyaror- } \\
\text { szági régió }\end{array}$ & 0,11 & $-0,40$ & $-0,41$ & $-0,41$ & 0,09 & $-0,34$ & $-0,40$ & 0,33 \\
\hline $\begin{array}{l}\text { Észak-alföldi } \\
\text { régió }\end{array}$ & 0,10 & $-0,39$ & $-0,40$ & $-0,41$ & $-0,28$ & $-0,13$ & $-0,41$ & 0,16 \\
\hline $\begin{array}{l}\text { Tisza-tavi } \\
\text { régió }\end{array}$ & $-0,02$ & $-0,41$ & $-0,41$ & $-0,41$ & $-0,32$ & $-0,39$ & $-0,41$ & $-0,29$ \\
\hline $\begin{array}{l}\text { Dél-alföldi } \\
\text { régió }\end{array}$ & 0,08 & $-0,38$ & $-0,40$ & $-0,38$ & $-0,22$ & $-0,37$ & $-0,35$ & 0,04 \\
\hline $\begin{array}{l}\text { Közép- } \\
\text { dunántúli } \\
\text { régió }\end{array}$ & 0,05 & $-0,39$ & $-0,40$ & $-0,39$ & $-0,16$ & $-0,40$ & $-0,40$ & $-0,02$ \\
\hline $\begin{array}{l}\text { Balatoni } \\
\text { régió }\end{array}$ & 0,13 & $-0,65$ & $-0,64$ & $-0,61$ & $-0,18$ & $-0,39$ & $-0,40$ & $-0,67$ \\
\hline $\begin{array}{l}\text { Dél- } \\
\text { dunántúli } \\
\text { régió }\end{array}$ & 0,05 & $-0,38$ & $-0,40$ & $-0,29$ & $-0,25$ & $-0,40$ & $-0,41$ & $-0,01$ \\
\hline $\begin{array}{l}\text { Nyugat- } \\
\text { dunántúli } \\
\text { régió }\end{array}$ & 0,05 & $-0,41$ & $-0,56$ & $-0,40$ & $-0,39$ & $-0,41$ & $-0,41$ & $-0,46$ \\
\hline $\begin{array}{l}\text { Idegenfor- } \\
\text { galmi régiók } \\
\text { összesen }\end{array}$ & $-0,57$ & $-1,02$ & $-0,83$ & $-0,44$ & 1,38 & 0,02 & $-0,42$ & 0,20 \\
\hline
\end{tabular}

Forrás: Saját számítás.

Országosan megállapíthatjuk, hogy az elméleti áramlások némileg magasabbak a valós áramlásoknál. A kiindulási tervezési-statisztikai régiók közül a KözépDunántúlról kiinduló áramlás haladja meg legnagyobb mértékben az elméleti értéket. Az elméletihez képest erősebb turisztikai áramlás indul még ki a NyugatDunántúlról, Közép-Magyarországról, Dél-Dunántúlról, illetve a Dél-Alföldről. Ezzel szemben elsősorban Észak-Magyarország, de kismértékben Észak-Alföld esetében is a valós áramlás mértéke elmarad az elméleti mozgás mértékétől. 
A fogadó idegenforgalmi régiók vonatkozásában messze kiemelkedik BudapestKözép-Dunavidék. Ide az elméletileg előre jelzettnél jóval nagyobb mértékben érkeznek belföldi turisták. Ebbe az idegenforgalmi régióba valamennyi turisztikai régióból több turista érkezik, mint az elméletileg várható lenne. Hasonló, pozitív eltérést láthatunk még a Balatoni, a Nyugat-dunántúli és a Tisza-tavi régió esetében is. Az első két idegenforgalmi régióba csak Közép-Magyarországról, míg az utóbbiba valamennyi régióból az elöre jelzettnél többen érkeznek.

Sajnálatos módon 3 kelet-magyarországi idegenforgalmi régióba érkező belföldi turisták száma alacsonyabb, mint az elméleti érték. Legjelentősebb elmaradást az Északmagyarországi régiónál láthatjuk, melyet az Észak-alföldi és a Dél-alföldi követ.

Az egyes mozgásokat részletesen vizsgálva leginkább a Közép-Magyarországról kiinduló és a Budapest-Közép-dunavidéki régióba tartó áramlás kiemelkedő szerepe tủnik ki. A két féle régió (tervezési-statisztikai és idegenforgalmi) között ebben az esetben van ugyan néhány településnyi eltérés, de ettől függetlenül alapvetően a régión belüli mozgásról beszélünk, mely ebben az esetben jóval erősebb, mint azt a modell alapján becsülhetnénk.

A többi idegenforgalmi régió esetében érdemes elkülöníteni a dunántúli és a keletmagyarországi régiókat. A dunántúliak esetében elsősorban a szomszédos régiókba való áramlás szerepe, míg a keletieknél egyes dunántúli régiók felkeresése jelentősebb az elméleti áramlásnál.

\section{Összegzés}

Vizsgálatunk is rámutatott arra, hogy az elérhetöség növekedése és a bevételek növekedése között nincs feltétlen kapcsolat. A külföldi bevételek jóval érzékenyebbek a kedvező elérhetőségi helyzetre, mint a belföldiek.

A régiók szerepe az idegenforgalmi bevételek kialakulására meglehetősen jelentős különbségeket mutat. A külföldi és a belföldi bevétel között nagy kölcsönhatási különbségeket figyelhettünk meg, melynek oka elsősorban a külföldi bevételek igen erös területi koncentrációját mutatja, míg ehhez képest a belföldieknél jóval egyenletesebb az eloszlás.

A bevételek nagysága vonatkozásában fontos még a régiók és az elérhetőségi csoportok közötti interakció szerepe is. Ebben megállapítottuk, hogy mind a 4 elérhetöségi csoport vonatkozásában - a külföldi és belföldi bevételeknél is - azonos régiókban a legmagasabb a szorzó. A különbség a szorzók nagyságában látható, mely a külföldi és belföldi bevételek közötti területi, illetve elérhetőségi különbségeket mutatja.

Az elméleti és a valós turisztikai áramlások kuilönbségéből arra a következtetésre jutottunk, hogy országosan az elméleti áramlások némileg magasabbak a valós áramlásoknál. A kiindulási tervezési-statisztikai régiók esetében elsősorban a régiók anyagi fejlettsége a meghatározó erejü, így leginkább Közép-Magyarország és a dunántúli régiók emelhetők ki. A fogadó idegenforgalmi régiók vonatkozásában messze kiemelkedik Budapest-Közép-Dunavidék. Hasonló, pozitiv eltérést látha- 
Tóth Géza - Dávid Lóránt : Az elérhetőség és az idegenforgalom kapcsolata.

Tér és Társadalom 23. évf. 2009/3. 45-62. p.

tunk még a Balatoni, a Nyugat-dunántúli és a Tisza-tavi régió esetében is. Ez a tény is mutatja fejlesztési lehetőségeiket.

Sajnálatos módon 3 kelet-magyarországi idegenforgalmi régióba érkező belföldi turisták száma alacsonyabb, mint az elméleti érték.

\section{Irodalom}

Dusek, T. (2003) A gravitációs modell és a gravitációs törvény összehasonlitása. - Tér és Társadalom. 1. 41-58. 0 .

Füstös L. (1985) Loglineáris modell kontingencia-táblák elemzésére. MTA Szociológiai Kutató Intézet, Budapest.

Geurs, K.T.-Ritsema, van Eck J.R. (2001) Accessibility measures: review and applications. Evaluation of accessibility impacts of land-use transportation scenarios, and related social and economic impact. Report no. $408505006 \mathrm{http}: / /$ www.mnp.nl/bibliotheek/rapporten/408505006.pdf

Hale, C.M.-Page, S.J. (1999) Geography of Recreation and Tourism: Place and Space. Routledge, London. Halsall, D. (ed.) (1982) Transport for Recreation. IBG Transport Geography Study Group, Lancaster.

Isard, W.-Azis, I.J.-Drennan, M.P.-Miller, RE.-Salzman, S.-Thorbecke, E. (1998) Methods of Interregional and Regional Analysis. Ashgate, Aldershot.

Knowles, R. (1993) Research agendas for transport geography in 1990s. - Journal of Transport Geography. 1. 3-11.0.

KSH (2008) Jelentés a turizmus 2007 évi teljesítményéröl. Központi Statisztikai Hivatal, Budapest.

Stewart, J.Q. (1948) Demographic Gravitation: Evidence and Applications. - Sociometry. FebruaryMay. 31-58. o.

\section{THE CONNECTION BETWEEN ACCESSIBILITY AND TOURISM}

\section{GÉZA TÓTH - LÓRÁNT DÁVID}

The examination of the relations between tourism and road accessibility raises a large number of methodological problems. Although the connection may seem evident, the statistical measurement is rather difficult. Thus we did not intend to examine the strength of the connection, rather its characteristics and components in the Hungarian tourist regions by means of the loglinear model. In the second part of our analysis we tried to predict the length of multi-day domestic holidays by means of the gravity model after which the real and the predicted data were also compared. This is how we attempted to reveal the characteristics of the Hungarian domestic tourist flow. 